\title{
Persepsi Konsumen Terhadap Bahan dan Disain Kemasan Jambu Kristal (psidium guajava) Ramah Lingkungan
}

\section{The Consumer's Perception of the Eco-Friendly Crystal Guava (psidium guajava) Packaging Materials and Design}

\author{
Anak Agung Gede Angga Surya Mayura, I Nyoman Sucipta*, Pande Ketut Diah Kencana \\ Program Studi Teknik Pertanian dan Biosistem, Fakultas Teknologi Pertanian, Universitas Udayana, Badung, Bali, \\ Indonesia \\ *Email: sucipta@unud.ac.id
}

\begin{abstract}
Abstrak
Kemasan sudah diketahui sejak manusia mengenal sistem penyimpanan bahan makanan. Kemasan meliputi tiga jenis, yaitu merek, kemasan itu sendiri dan label. Tujuan dilakukannya pengemasan selain sebagai pelindung terhadap produk agar tidak mudah rusak, juga bertujuan agar memiliki daya tarik bagi konsumen agar tertarik untuk menikmati produk tersebut. Adapun penelitian bertujuan untuk: (1) Menentukan persepsi konsumen terhadap kualitas kemasan. (2) Menentukan persepsi konsumen terhadap disain kemasan. (3) Menentukan persepsi Konsumen terhadap harga kemasan primer dan sekunder. (4) Menentukan persepsi konsumen terhadap kepuasan pada kemasan. Tempat penelitian dilakukan di pasar Badung dan pasar Sukawati. Sampel penelitian adalah konsumen/pengunjung di pasar Badung dan pasar Sukawati pada periode bulan Juli 2020 sampai dengan bulan Agustus 2020 sebanyak 50 konsumen. Pengolahan data menggunakan alat bantu SPSS 25 dengan menggunakan metode analisis deskriptif kuantitatif. Dari hasil penelitian yang dapat disimpulkan, kemasan yang dominan menurut perpsepsi 50 responden dari segi kualitas adalah kemasan daun kelapa dengan hasil 29 orang/(58\%) memilih setuju. Dari segi bahan dan disain adalah kemasan anyaman bambu dengan hasil, 29 orang/(58\%) memilih setuju. Dari segi harga adalah kemasan anyaman bambu dengan hasil 31 orang/(62\%) memilih sangat setuju (5). Dari segi kepuasan adalah kemasan daun kelapa dengan hasil, 40 orang/(80\%) memilih setuju (4).
\end{abstract}

Kata kunci: Persepsi Konsumen, Kualitas Produk, Disain Kemasan

\begin{abstract}
Packaging has been known since humans knew about food storage systems. Packaging includes three things, namely the brand, the packaging itself and the label. The purpose of packaging is not only to protect the product from being easily damaged, but also to attract consumers to be interested in enjoying the product. The research aims to: (1) Determine consumer perceptions of packaging quality. (2) Determine consumer perceptions of packaging design. (3) Determine consumer perceptions of primary and secondary packaging prices. (4) Determine consumer perceptions of satisfaction with packaging. The research site was conducted in Badung market and Sukawati market. The research sample is consumers / visitors in Badung market and Sukawati market in the period from July 2020 to August 2020 as many as 50 consumers. Data processing used the SPSS 25 tool using quantitative descriptive analysis method. From the results of the study it can be concluded that the dominant packaging according to the perceptions of 50 respondents in terms of quality is coconut leaf packaging with the results 29 people / $(58 \%)$ chose to agree. In terms of material and design, the packaging was woven bamboo with the result, 29 people / (58\%) agreed. In terms of price, the packaging was woven bamboo with the result that 31 people / (62\%) strongly agreed (5). In terms of satisfaction, the packaging of coconut leaves with results, 40 people / $(80 \%)$ chose to agree (4).
\end{abstract}

Keywords: Consumer Perception, Product Quality, Packaging Design

\section{PENDAHULUAN}

Jambu biji kristal (Psidium guajava) adalah salah suatu tanaman buah yang sudah sangat dikenal di Indonesia. Buah jambu biji kristal dapat di budidayakan di Indonesia, jambu biji kristal merupakan mutasi dari residu Muangthai Pak. Buah jambu kristal ditemukan pada tahun 1991 di District Kao Shiung-Taiwan. Buah jambu Kristal mulai diperkenalkan di Indonesia pada tahun 1991 oleh Misi Teknik Taiwan yang bekerja sama dengan 
Institut Pertanian Bogor (IPB). Buah jambu kristal adalah buah yang hampir tidak berbiji, jumlah bijinya kurang dari 3\% bagian buah, jambu biji Kristal adalah jenis buah jambu yang hampir tidak berbiji (Rahman, 2011). Kemasan pada buah jambu kristal umumnya menggunakan kemasan busa jaring atau wrap plastic yang kemudian di jual ke pasar (Titisari, 2013). Berdasarkan lingkup pengertian yang telah berkembang, definisi pengemasan tercakup dalam tiga aspek, yaitu pengemasan yang berarti sebagai suatu alat penyampaian, pengemasan sebagai suatu sistem penyiapan produk, dan pengemasan sebagai suatu fungsi penyampaian produk (Syukri, 2014).

Bahan plastik yang sering kita jumpai sekarang ini berjenis bakelit dan ditemukan oleh Leo Hendrik Baekeland, kemudian mulai diperkenalkan kepada masyarakat pada tahun 1910 (Dede Nurrosyid, 2006). Kemasan adalah suatu kegiatan merancang dan memproduksi bungkus suatu barang yang meliputi desain bungkus dan pembuatan bungkus produk tersebut. (Suherlan, Y., Muttaqin, H., Anam, C., \& Widiyanti, 2016). Bahan pengemasan yang paling umum digunakan untuk pengemasan bahan pangan dapat dibedakan berdasarkan bahannya, yaitu: kemasan kaca/gelas, kemasan logam, kemasan plastik, kemasan kertas dan kemasan logam (Yuliati, Y., \& Hadiyati, 2018)). Salah satu hal yang perlu dicermati adalah sikap positif konsumen Indonesia terhadap produk ramah lingkungan masih didominasi oleh emosional, Hal ini bisa dilihat dari masih minimnya pengetahuan konsumen mengenai klaim ramah lingkungan (FAJRIL, 2015). Permasalahan lingkungan menjadi salah satu isu strategis dalam meraih daya saing

global. Salah satunya adalah munculnya produk produk yang terbuat dari bahan bahan ramah lingkungan atau dikenal dengan istilah green product (Santoso, I., \& Fitriani, 2016). Dalam penelitian yang telah dilakukan ini Jambu biji kristal dikemas dengan berbagai desain kemasan contohnya kemasan dengan anyaman daun kelapa, anyaman daun lontar kering, kemasan busa jaring dan anyaman bamb. Mengingat keunggulan bahan plastik yang memang tergolong kuat, tahan lama, dan tidak mudah rusak dalam memenuhi kebutuhan manusia sebagai bahan yang digunakan sebagai kemasan menyebabkan penggunaan plastik sebagai pengemas mengalami peningkatan setiap tahunnya baik secara Nasional maupun Internasional (Pudjiastuti, 2010). Hal ini dikarenakan plastik dapat dibuat dalam berbagai bentuk. Plastik ini berdampak negatif bagi lingkungan seperti limbahnya yang sulit terurai, padahal penggunaanya yang terus meningkat tiap tahunnya (Priambodo, 2017).

Penggunaan bahan kemasan plastik turut menciptakan masalah yang sangat serius bagi lingkungan dalam menangani sampah plastik dimana $60 \%$ bentuk kemasan (Firdaus et al., 2008) dan limbah cair dengan volume $440 \mathrm{~km} 3$ per tahunnya, seiring dengan adanya himbauan dari pemerintah yang telah mengarahkan kepada masyarakat untuk mengurangi penggunaan sampah plastikmaka dari itu didalam penelitian ini digunakan bahan kemasan ramah lingkungan sebagai inovasi baru seperti contohnya, daun kelapa, daun lontar kering, dan anyaman bambu

Konsumen menginginkan bentuk kemasan yang membuat produk dalam kondisi tetap baik sehingga dapat berguna bagi kesehatan dan meningkatkan kualitas hidup mereka.Mereka juga ingin produk yang kemasannya ramah lingkungan (Cindy, 2016). Kemasan ramah lingkungan adalah kemasan yang menggunakan bahan-bahan yang mudah diurai, bisa didaur ulang, serta tidak berbahaya bagi lingkungan maupun manusia. Desain kemasan yang dibuat dengan bahan dasar daun kelapa, daun lontar kering dan bambu biasanya ditampilkan dalam bentuk anyaman. Daun kelapa dibuat menyerupai tas belanja, sedangkan pada daun lontar kering berbentuk kotak seperti keranjang buah yang biasa ditemui di pasar. Penggunaan anyaman bambu sebagai bahan pengemas biasanya digunakan pada buah-buahan, penggunaan anyaman bambu dengan permukaan yang halus, dengan bobot yang terbatas, atau untuk hasil olahan dengan dilapisi daun, yang bertujuan agar produk yang dikemas tidak keluar dari jalinan anyaman dan tidak terkontaminasi oleh kotoran dan air dari luar. Kelebihan dari kemasan yang terbuat dari anyaman bambu adalah mampu menjaga kelembaban udara, dan dengan sifatnya yang opak, dapat melindungi bahan yang dikemasnya terhindar dari reaksi penguraian yang diakibatkan oleh sinar dan gesekan.

\section{METODE PENELITIAN}

Penelitian ini menggunakan pendekatan deskriptif kuantitatif dan metode pengumpulan data yang dilakukan melalui penggunaan kuisioner Menurut (Sarnawi M Dasim, 2012) "survei ditujukan untuk memperoleh gambaran umum tentang karakteristik populasi," yang mana "dapat digunakan untuk mengumpulkan data berkenaan dengan sikap, nilai, 
kepercayaan, pendapat, pendirian, keinginan, citacita, perilaku, kebiasaan, dll.".

\section{Tempat dan waktu penelitian}

Penelitian ini dilaksanakan pada awal bulan Januari 2020 sampai dengan akhir bulan Januari 2020. Perancangan beberapa desain kemasan yang akan digunakan untuk mengemas Jambu Kristal di lakukan di Lab. Rekayasa Alat dan Ergonomika. Sedangkan uji penilaian persepesi terhadap penerimaan masyarakat konsumen terhadap disain yang diusulkan dalam penelitian ini dilakukan di dua tempat, yaitu Pasar Sukawati yang beralamat di Jl. Raya Sukawati, Kec. Sukawati, Kab Gianyar dan Pasar Badung yang beralamat di Jl. Sulawesi, Dauh Puri Kangin, Kec. Denpasar Barat, Kota Denpasar, Bali.

\section{Bahan Penelitian}

Pada bahan penelitian ini yaitu menggunakan buah jambu kristal, anyaman daun kelapa, anyaman bambu, anyaman daun lontar kering dan busa jaring yang biasa digunakan untuk membungkus jambu kristal, dengan menggunakan alat yaitu: pisau, gunting, gergaji dan lem.

\section{Variabel Penelitian}

Penelitian ini terdiri dari dua variabel yaitu variabel bebas dan variable tergantung.

a. Variabel bebas dalam penelitian ini yaitu.

1. Jambu Kristal dikemas dengan daun kelapa hijau

2. Jambu Kristal dikemas dengan daun lontar kering

3. Jambu Kristal dikemas dengan busa jaring

4. Jambu Kristal dikemas dengan anyaman bambu (bambu tali atau bambu apus)

b. Variabel tergantung (dependen variable)

Yang termasuk variable tergantung yaitu: Persepsi responden terhadap kualitas kemasan, disain kemasan, harga kemasan, kepuasan konsumen terhadap kemasan.

\section{Sampel}

Berikut ini akan dijabarkan sampel yang digunakan dalam penelitian ini:

\section{Besar Sampel}

Untuk menentukan sasaran sampel adalah secara proposive yaitu ditetapkan sesuai dengan tujuan penelitian. Pada penelitian ini sasaran sampel adalah pedagang yang memenuhi kriteria sampel di lokasi pasar Badung Denpasar. Sampel pada penelitian ini dengan kriteria sebagai berikut:

a. Kreteria Inklusi

- Jenis kelamin laki-laki dan perempuan

- Umur 20-50 tahun

b. Kreteria Eksklusi

- Pedagang buah
- Bersedia menjadi subyek penelitian sampai selesai.

- Berpengalaman sebagai pedagang buah minimal 1 tahun.

\section{Tahapan Pelaksanaan Penelitian}

Tahapan penelitian dilakukan dalam melalui beberapa tahapan, pembuatan disain kemasan dan survei lapangan.

\section{Pembuatan Desain Kemasan}

Pengertian desain menurut (Archer, 1965) adalah bidang keterampilan, pengetahuan dan pengalaman manusia yang mencerminkan keterikatannya dengan apresiasi dan adaptasi lingkungannya ditinjau dari kebutuhan-kebutuhan kerohanian dan kebendaannya. Dalam penelitian ini adapun bahan yang digunakan adalah salah satunya daun kelapa yang masih hijau. Dalam pembuatan kemasan ramah lingkungan menggunakan bahan daun kelapa, daun lontar kering dan bambu dan perlakuan yang dilakukan adalah dengan cara menganyam daun kelapa hingga terbentuk seperti keranjang buah berbentuk bulat pada umumnya, namun pada disain kemasan yang akan dibuat yaitu berbentuk kotak. Untuk anyaman daun kelapa, anyaman daun lontar kering dan anyaman bambu. Setelah anyaman selesai dibuat buah jambu kristal dimasukan terlebih dahulu sebelum kemasan diikat pada bagian atasnya, dikarenakan anyaman yang dibuat memiliki karakter anyaman yang cukup rapat.Pada bahan kemasan sering ditambahkan bahan-bahan lain yang bertujuan untuk meningkatkan fungsi kemasan dan daya tarik kemasan tersebut, diantaranya yaitu: pita perekat, pita sensitif tekanan, label, sticker, tag, strapping, dan bantalan pelindung (Sucipta, I N., 2016).

\section{Survei lapangan.}

Metode survei adalah studi yang sumber utama data dan informasinya diperoleh oleh responden sebagai sampel survei menggunakan kuesioner.

Instrument pengumpulan data dengan memberikan sejumlah pertanyaan atau pernyataan tertulis kepada responden untuk dijawabnya (Markkanen, 2004). Instrumen pengumpulan data dalam penelitian ini berupa kuesioner atau angket yang disusun berdasarkan komponen-komponen yang diperlukan dalam analisis data. Selain menggunakan kuesioner, dalam penelitian ini juga menggunakan beberapa peralatan pendukung dalam pengumpulan data. Seperti kamera video dan peralatan lainnya.

\section{Metode Analisis Data}

Dalam penelitian ini, metode analisis data yang digunakan dalam penelitian ini adalah metode 
deskriptif kuantitatif dengan menggunakan SPSS versi 25 , uji validitas dan uji reabilitas sebagai aplikasi olah data.

\section{Langkah-langkah yang akan dilakukan adalah sebagai berikut: Validitas}

Uji validitas digunakan untuk mengetahui sejauh mana alat ukur yang digunakan dalam mengukur apa yang diukur. Ghozali, (2009) mengatakan bahwa uji validitas adalah uji yang digunakan untuk mengukur sah, atau valid tidaknya suatu kuesioner. Uji validitas yaitu uji yang dilakukan secara statistik yaitu dengan teknik korelasi, dengan membandingkan nilai korelasi yakni $r$ hitung dengan $r$ table, apabila $r$ hitung dinyatakan lebih besar dari $r$ table, maka dapat disimpulkan bahwa instrument adalah valid.

\section{Reabilitas}

Uji reabilitas adalah uji untuk memastikan apakah kuesioner penelitian yang akan digunakan untuk menggunakan data variable penelitian reliable atau tidak. Uji reabilitas yaitu suatu pengujian yang berorientasi pada derajat stabilitas, konsistensi, daya prediksi, dan akurasi. Uji ini dilakukan agar melihat kesesuaian nilai dari suatu kuesioner yang dikerjakan oleh responden pada waktu yang berbeda dengan kuesioner yang sama.

\section{HASIL DAN PEMBAHASAN}

\section{Kemasan Ramah Lingkungan}

Kemasan ramah lingkungan adalah kemasan yang menggunakan bahan-bahan yang mudah terurai, dapat didaur ulang dan tidak berbahaya bagi lingkungan maupun manusia. Kemasan ramah lingkungan merupakan suatu upaya untuk melestarikan lingkungan, kesadaran masyarakat terhadap pentingnya menjaga kelestarian lingkungan hidup membuat banyak produsen dari berbagai macam produk beralih menggunakan bahan-bahan yang tidak merusak lingkungan atau istilah lainnya bahan yang ramah lingkungan (Ratnawati \& Putranti, 2016). Penggunaan kemasan ramah lingkungan terhadap suatu produk kini juga sudah menjadi sebuah tren internasional. Dimana, ide penggunaan kemasan ramah lingkungan ini telah dikenal dan berkembang terlebih dahulu di kalangan warga asing. Saat ini para pelaku industri di negara Indonesia juga memperhatikan hal ini sebagai suatu peluang agar dapat mengembangkan dan mengikuti tren saat ini, agar nantinya para pelaku industri di Indonesia tidak tersisih dalam persaingan global. Penggunaan kemasan ramah lingkungan adalah suatu kebutuhan yang memang perlu di terapkan oleh setiap pelaku industri di Indonesia, mengingat adanya isu-isu mengenai bahaya dari limbah yang berasal dari sampah plastik. Kali ini kemasan ramah lingkungan dibuat dengan 2 bagian seperti halnya kemasan buah yang biasa ditemui di pasar yaitu ada bagian dalam dan bagian luar dimana, kemasan bagian dalam yang berinteraksi langsung dengan buah berfungsi untuk melindungi buah dari gesekangesekan, sedangkan bagian luar sebagai wadah untuk buah yang tentunya di disain dengan bahan yang cukup kuat. MenurutHarris, (2001), ada lima syarat kemasan yaitu penampilan, perlindungan,fungsi, harga dan biaya, Adapun kemasan ramah lingkungan yang akan digunakan dalam penelitian ini sebagai berikut:

\section{Kemasan Daun Kelapa}

Pembuatan kemasan anyaman daun kelapa yaitu menyerupai bentuk anyaman yang mirip dengan tas belanja. Pada bagian pelepah kelapa dimanfaatkan sebagai pegangan di bagianatas agar lebih kuat dalam mengemban beban buah, dengan ukuran yang tergolong ramping dengan panjang kemasan $37 \mathrm{~cm}$, lebar kemasan kurang lebih $5 \mathrm{~cm}$ dan tinggi kemasan $21 \mathrm{~cm}$. Dalam proses pembuatan menggunakan alat yaitu: pisau dan gunting untuk memotong daun, tali yang terbuat dari bambu tali/bambu apus

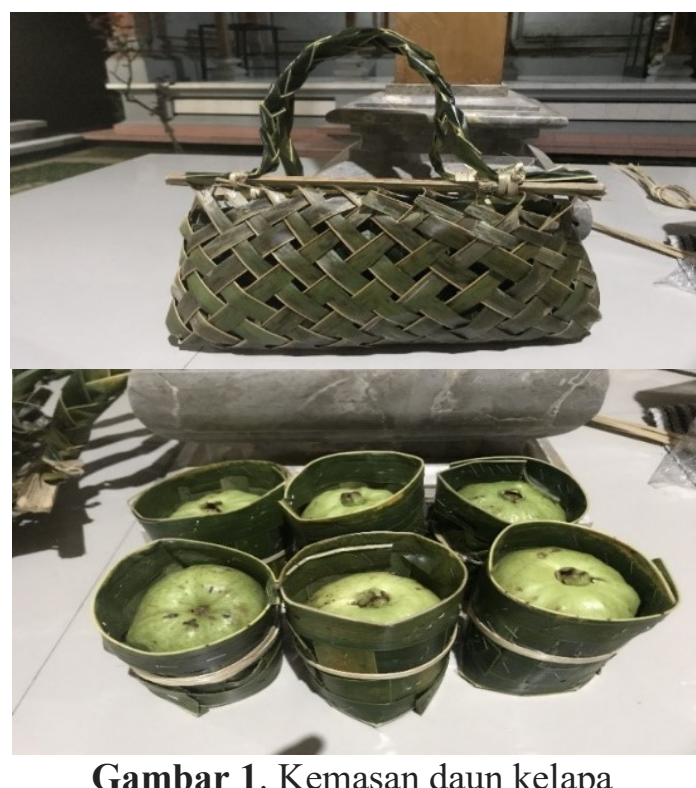

\section{Kemasan Daun Lontar Kering}

Kemasan daun lontar kering dibuat menyerupai bentuk anyaman, dimana anyaman daun lontar kering berbentuk kotak seperti keranjang buah yang biasa ditemui di pasar, dengan panjang kemasan yaitu 32 $\mathrm{cm}$, lebar kemasan $23 \mathrm{~cm}$, dan tinggi kemasan $12 \mathrm{~cm}$. 


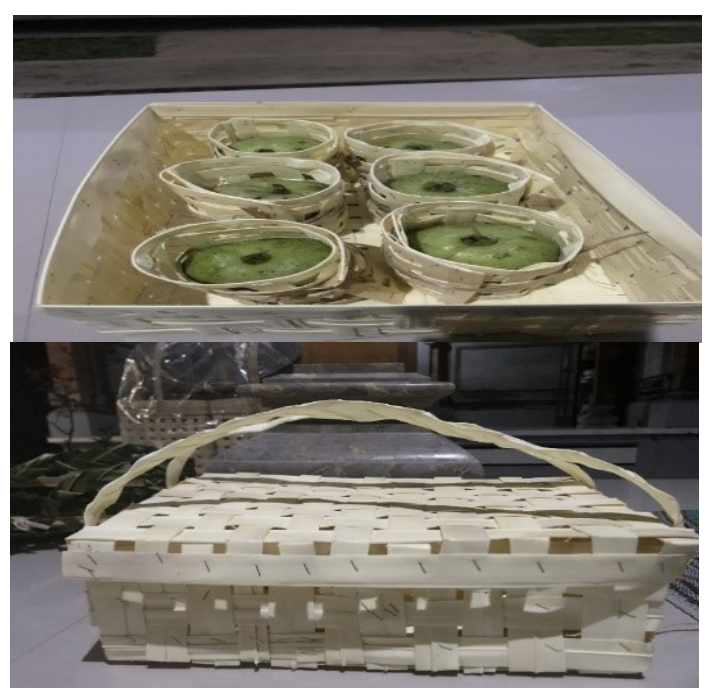

Gambar 2. Kemasan daun lontar kering

\section{Kemasan Anyaman Bambu}

Kemasan anyaman bambu juga dibuat menyerupai bentuk anyaman, dimana kemasan anyaman bambu dibuat berbentuk vertikal dengan panjang kemasan yaitu $18 \mathrm{~cm}$, lebar kemasan $18 \mathrm{~cm}$ dan tinggi kemasan $25 \mathrm{~cm}$. Pada bahan dasar kemasan anyaman bambu menggunakan bambu tali/bambu apus dimana, bagian bambuyang digunakan adalah bagian dalamnya yang dibersihkan hingga halus agar tidak merusak kondisi buah saat dilakukannya pengemasan.

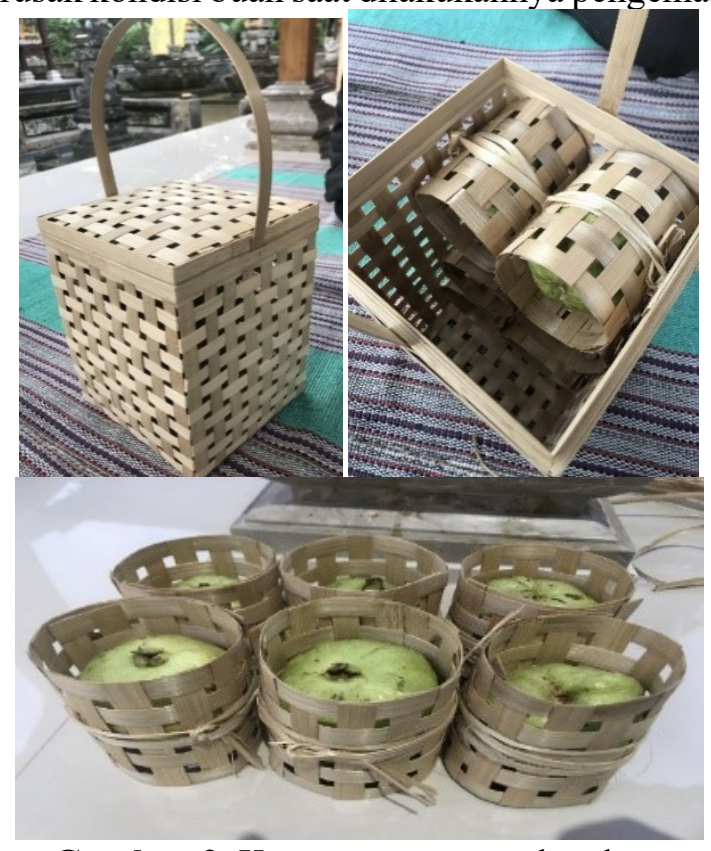

Gambar 3. Kemasan anyaman bamboo

\section{Pembahasan Hasil Persepsi Konsumen Terhadap Kualitas Kemasan}

Berdasarkan hasil survei kuesioner 4 kemasan dari 50 responden dapat disimpulkan bahwa kemasan anyaman daun kelapa paling disukai berdasarkan survei dengan hasil dari 50 responden yaitu, 10 orang/(20\%) memilih netral, 29 orang/(58\%) memilih setuju dan 11 orang/(22\%) memilih sangat setuju (5). Dibandingkan kemasan lain seperti kemasan daun lontar kering dari 50 responden yaitu, 14 orang/(28\%) memilih tidak setuju, 29 orang/(58\%) memilih netral dan 7 orang/(14\%) memilih setuju (4), kemasan busa jaring dari 50 responden yaitu, 33 orang/(66\%) memilih netral dan 17 orang/(34\%) memilih setuju dan kemasan anyaman bambu dari 50 responden yaitu, 29 orang/(58\%) memilih netral, 21 orang/(42\%) memilih setuju (4). Menurut (Noviadji, 2014) penampilan pada kemasan tradisional daun kelapa terlihat lebih alami mulai dari warna, tekstur, dan bentuknya. Menurut responden dilapangan daun kalapa selain bahannya yang mudah didapat walaupun daunnya berubah yang awalnya berwarna hijau menjadi cokelat, daun kelapa tergolong cukup kuat untuk dijadikan kemasan buah dengan adanya lidi didalamnya.

\section{Kemasan primer}

\section{a. Kemasan busa jaring}

Hasil analisis data kuesioner dari persepsi responden pada penelitian yang telah dilaksanakan menyatakan bahwa persepsi konsumen terhadap kualitas kemasan busa jaring dari 50 responden yaitu, 33 orang/(66\%) memilih netral dan 17 orang/(34\%) memilih setuju (4)

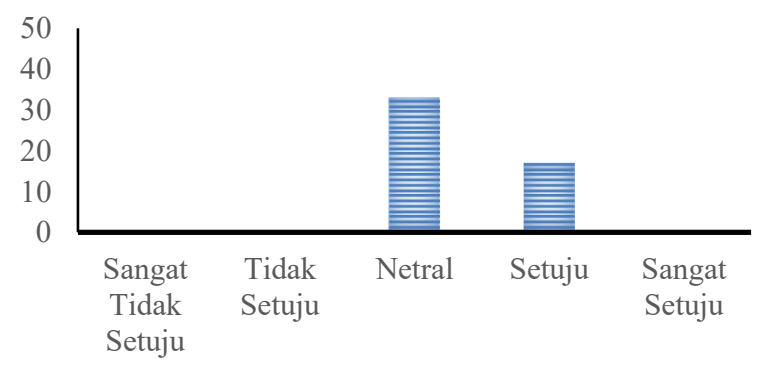

Gambar 4. Histogram persepsi kemasan busa jaring

\section{Kemasan Sekunder}

a. Kemasan daun kelapa

Hasil analisis data kuesioner dari persepsi responden pada penelitian yang telah dilaksanakan menyatakan bahwa persepsi konsumen terhadap kualitas kemasan anyaman daun kelapa dari 50 responden yaitu, 10 orang/(20\%) memilih netral, 29 orang/(58\%) memilih setuju dan 11 orang/(22\%) memilih sangat setuju (5). 


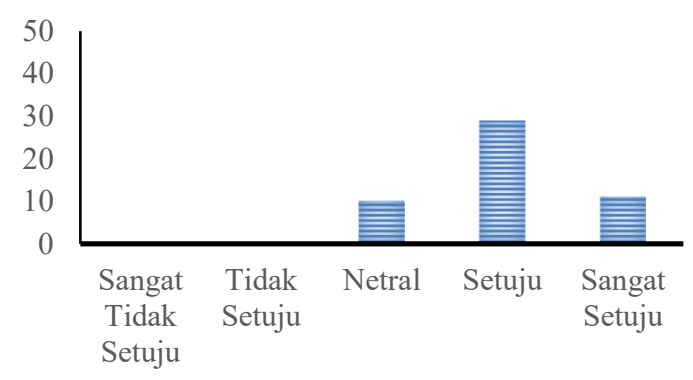

Gambar 5. Histogram persepsi kemasan daun kelapa

\section{b. Kemasan daun lontar kering}

Hasil analisis data kuesioner dari persepsi responden pada penelitian yang telah dilaksanakan menyatakan bahwa persepsi konsumen terhadap kualitas kemasan anyaman daun kelapa dari 50 responden yaitu, 10 orang/(20\%) memilih netral, 29 orang/(58\%) memilih setuju dan 11 orang/(22\%) memilih sangat setuju (5).

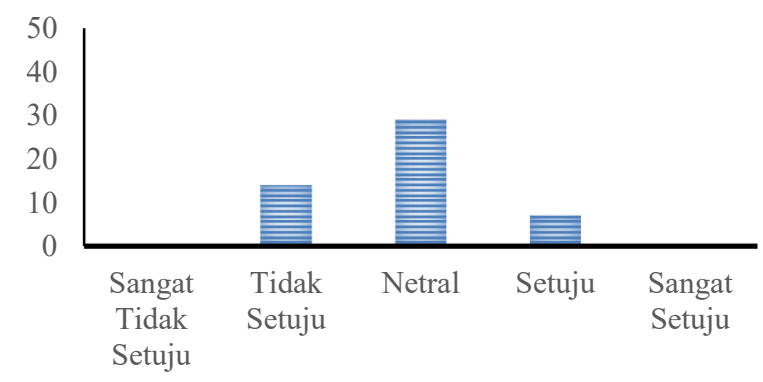

Gambar 6. Histogram persepsi kemasan daun lontar kering

\section{c. Kemasan anyaman bambu}

Hasil analisis data kuesioner dari persepsi responden pada penelitian yang telah dilaksanakan menyatakan bahwa persepsi konsumen terhadap kualitas kemasan anyaman bambu dari 50 responden yaitu, 29 orang/(58\%) memilih netral, 21 orang/(42\%) memilih setuju.

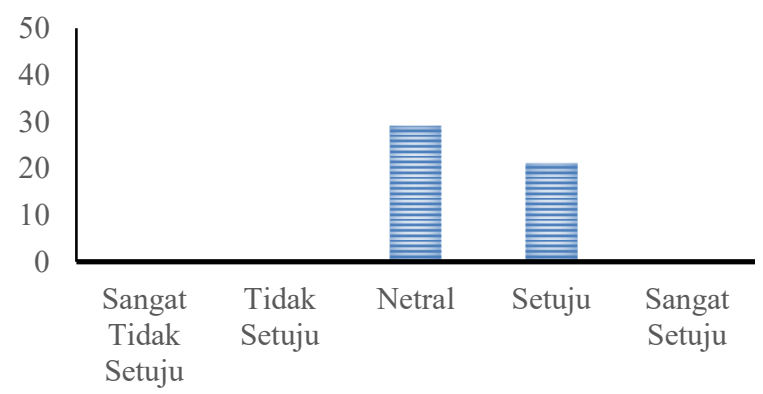

Gambar 7.Histogram persepsi kemasan anyaman bamboo

Pembahasan Hasil Persepsi Konsumen Terhadap Disain Kemasan

Berdasarkan hasil survei kuesioner 4 kemasan dari 50 responden dapat disimpulkan bahwa kemasan anyaman bambu paling disukai berdasarkan survei dengan hasil dari 50 responden yaitu, 10 orang/(20\%) memilih netral, 29 orang/(58\%) memilih setuju dan 11 orang/(22\%) memilih sangat setuju (5). Dibandingkan dengan kemasan lain seperti kemasan anyaman daun kelapa dengan hasil dari 50 responden yaitu, 2 orang/(4\%) memilih tidak setuju, 7 orang/(14\%) memilih netral dan 41 orang/(82\%) memilih setuju (4), kemasan daun lontar kering dari 50 responden yaitu, 26 orang/(52\%) memilih netral dan 24 orang/(48\%) memilih setuju dan kemasan busa jaring dari 50 responden yaitu, 44 orang/(88\%) memilih netral dan 6 orang/(12\%) memilih setuju (4). Menurut (Andrean et al., n.d.) Disain kemasan anyaman bambu diharapkan, kedepannya akan dapat lebih dikembangkan dengan rancangan disain kemasan yang lebih menarik atau inovatif. Dan menurut para responden dilapangan tentang disain kemasan bambu memang sangatlah menarik dibandingkan kemasan daun kelapa dan daun lontar kering dan menurut beberapa dari mereka disain kemasan daun kelapa menyerupai tempat ayam.

\section{Kemasan primer}

\section{Kemasan busa jaring}

Hasil analisis data kuesioner dari persepsi responden pada penelitian yang telah dilaksanakan menyatakan bahwa persepsi konsumen terhadap kualitas kemasan busa jaring dari 50 responden yaitu, 44 orang/(88\%) memilih netral dan 6 orang/(12\%) memilih setuju.

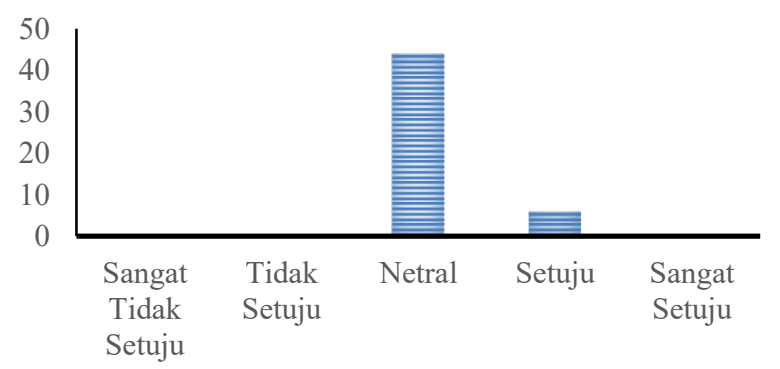

Gambar 8.Histogram persepsi kemasan busa jaring

\section{Kemasan Sekunder}

\section{Kemasan daun kelapa}

Hasil analisis data kuesioner dari persepsi responden pada penelitian yang telah dilaksanakan menyatakan bahwa persepsi konsumen terhadap kualitas kemasan anyaman daun kelapa dari 50 responden yaitu, 2 orang/(4\%) memilih tidak setuju , 7 orang/(14\%) memilih netral dan 41 orang/(82\%) memilih setuju 


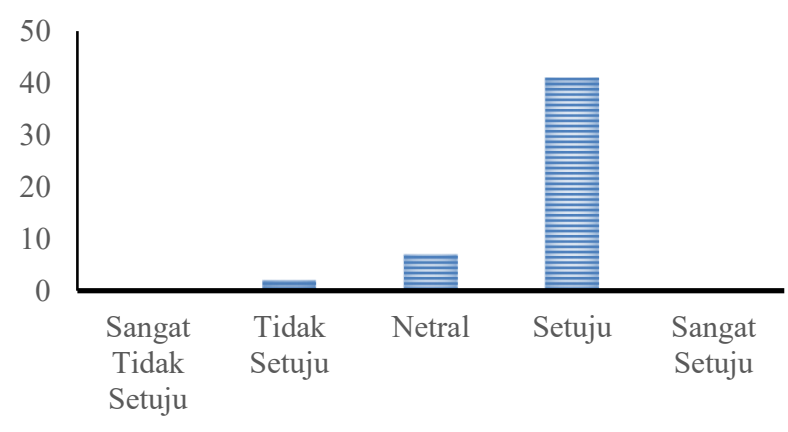

Gambar 9. Histogram persepsi kemasan anyaman daun kelapa

\section{Kemasan daun lontar kering}

Hasil analisis data kuesioner dari persepsi responden pada penelitian yang telah dilaksanakan menyatakan bahwa persepsi konsumen terhadap kualitas kemasan anyaman daun lontar kering dari 50 responden yaitu, 26 orang/(52\%) memilih netral dan 24orang/(48\%) memilih setuju.

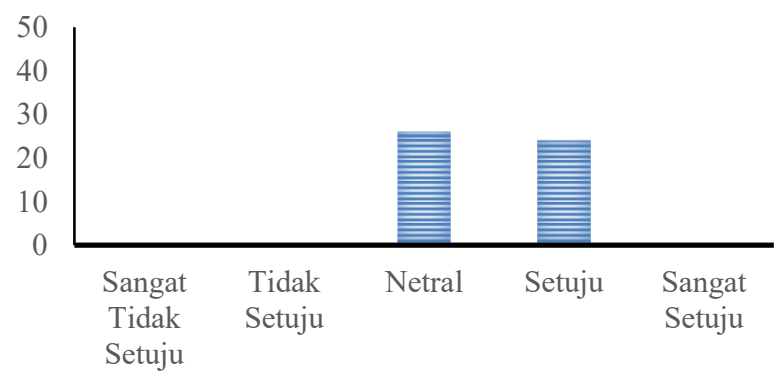

Gambar 10. Histogram persepsi kemasan daun lontar kering

\section{Kemasan Anyaman Bambu}

Hasil analisis data kuesioner dari persepsi responden pada penelitian yang telah dilaksanakan menyatakan bahwa persepsi konsumen terhadap kualitas kemasan anyaman bambu dari 50 responden yaitu, 10 orang/(20\%) memilih netral, 29 orang/(58\%) memilih setuju dan 11 orang/(22\%) memilih sangat setuju (5)

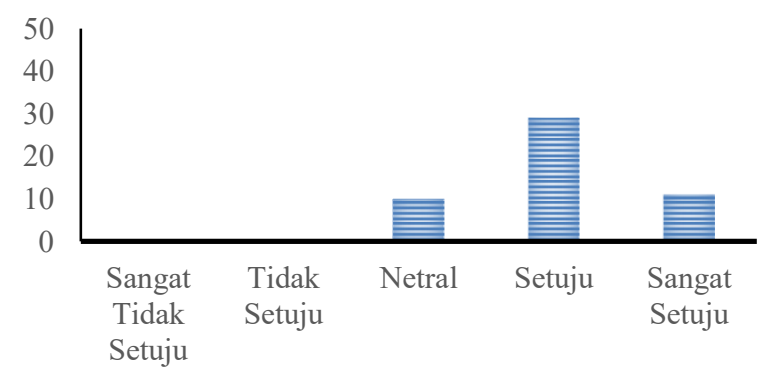

Gambar 11. Histogram persepsi kemasan anyaman bambu

\section{Pembahasan Hasil Persepsi Konsumen Terhadap harga Kemasan}

Berdasarkan hasil survei kuesioner 4 kemasan dari 50 responden dapat disimpulkan bahwa kemasan anyaman bambu paling disukai berdasarkan survei dengan hasil dari 50 responden yaitu, 3 orang/(6\%) memilih netral (3), 16 orang/(32\%) memilih setuju (4) dan 31 orang/(62\%) memilih sangat setuju (5), dibandingkan kemasan lain seperti kemasan daun kelapa dengan hasil dari 50 responden yaitu, 3 orang/(6\%) memilih tidak setuju (2), 10 orang/(20\%) memilih netral (3), 32 orang/(64\%) memilih setuju (4) dan 4 orang/(8\%) memilih sangat setuju (5). Kemasan daun lontar kering dari 50 responden yaitu, 1 orang/(2\%) memilih sangat tidak setuju (1), 11 orang/(22\%) memilih tidak setuju (2), 23 orang/(46\%) memilih netral (3), 10/orang (20\%) memilih setuju (4) dan 2 orang/(4\%) memilih sangat setuju (5) dan kemasan busa jaring dari 50 responden yaitu, 5 orang/(10\%) memilih tidak setuju, 4 orang $/(8 \%)$ memilih netral (3) dan 30 orang/(60\%) memilih setuju (4). Menurut (Andrean, R.A.) Kelebihan yang dimiliki dari kemasan yang terbuat dari anyaman bambu yaitu kemasan bambu dapat menjaga kelembaban udara dengan sifatnya yang opak kemasan berbahan bambu dapat melindungi buah yang dikemasnya terhindar dari reaksi penguraian yang disebabkan oleh cahaya. Dan menurut dari beberapa responden dilapangan menyatakan tentang harga kemasan bambu terbilang memang cukup mahal namun sesuai nilai estetikanya disainnya.

\section{a. Kemasan Primer}

\section{Kemasan busa jaring}

Hasil analisis data kuesioner dari persepsi responden pada penelitian yang telah dilaksanakan menyatakan bahwa persepsi konsumen terhadap harga kemasan busa jaring dari 50 responden yaitu, 5 orang/(10\%) memilih tidak setuju (2), 4 orang /(8\%) memilih netral (3) dan 30 orang/(60\%) memilih setuju (4)

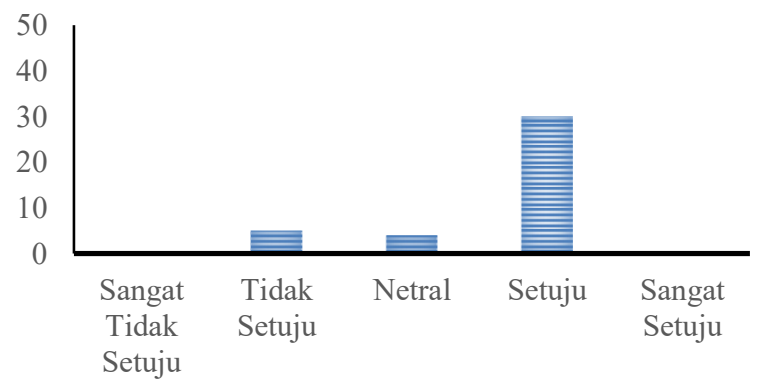

Gambar 12. Histogram persepsi kemasan busa jaring 


\section{b. Kemasan Sekunder}

\section{Kemasan daun kelapa}

Hasil analisis data kuesioner dari persepsi responden pada penelitian yang telah dilaksanakan menyatakan bahwa persepsi konsumen terhadap harga kemasan anyaman daun kelapa dari 50 responden yaitu, 3 orang/(6\%) memilih tidak setuju (2), 10 orang/(20\%) memilih netral (3), 32 orang/(64\%) memilih setuju (4) dan 4 orang/(8\%) memilih sangat setuju (5).

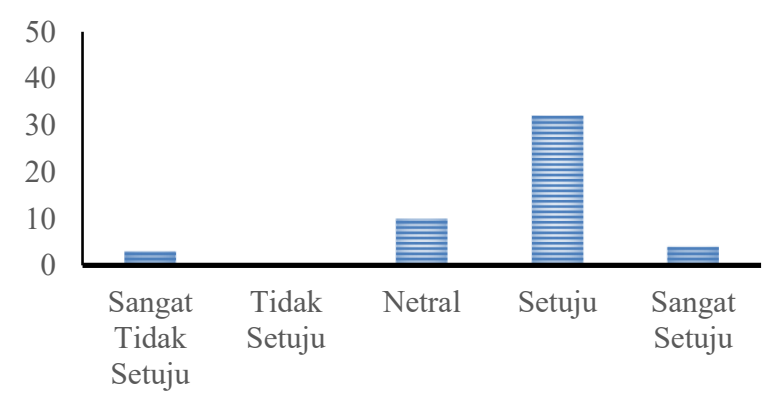

Gambar 13. Histogram persepsi kemasan daun kelapa

\section{2. Kemasan daun lontar kering}

Hasil analisis data kuesioner dari persepsi responden pada penelitian yang telah dilaksanakan menyatakan bahwa persepsi konsumen terhadap harga kemasan anyaman daun lontar kering dari 50 responden yaitu, 1 orang/(2\%) memilih sangat tidak setuju (1), 11 orang/(22\%) memilih tidak setuju (2), 23 orang/(46\%) memilih netral (3), 10/orang (20\%) memilih setuju (4) dan 2 orang/(4\%) memilih sangat setuju (5).

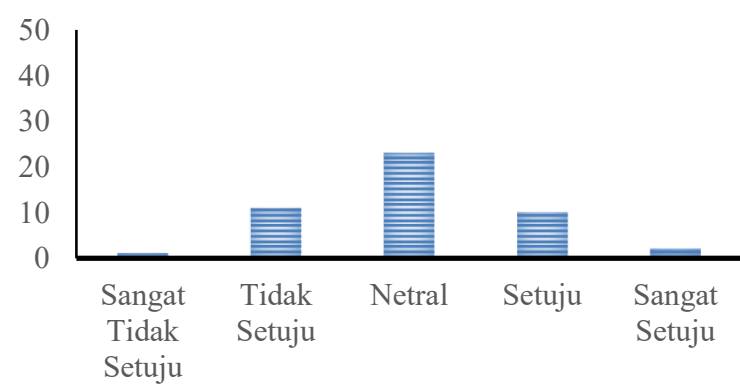

Gambar 14. Histogram persepsi kemasan daun lontar kering

\section{3. Kemasan anyaman bambu}

Hasil analisis data kuesioner dari persepsi responden pada penelitian yang telah dilaksanakan menyatakan bahwa persepsi konsumen terhadap kualitas kemasan anyaman bambu dari 50 responden yaitu, 3 orang/(6\%) memilih netral (3), 16 orang/(32\%) memilih setuju (4) dan 31 orang/(62\%) memilih sangat setuju (5)

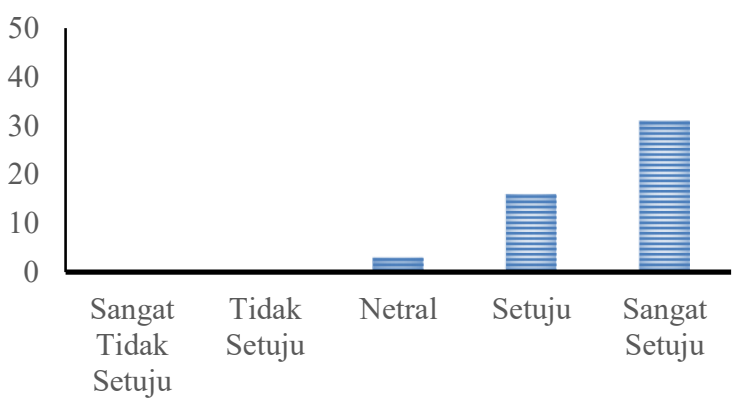

Gambar 15. Histogram persepsi kemasan anyaman bamboo

\section{Pembahasan Hasil Persepsi Konsumen Terhadap Kepuasan pada Kemasan}

Berdasarkan hasil survei kuesioner 4 kemasan dari 50 responden dapat disimpulkan bahwa kemasan anyaman daun kelapa paling disukai berdasarkan survei dengan hasil dari 50 responden yaitu, 6 orang/(12\%) memilih netral (3), 40 orang/(80\%) memilih setuju (4) dan 4 orang/(8\%) memilih sangat setuju (5). Dibandingkan kemasan yang lain seperti kemasan daun lontar kering dengan hasil dari 50 responden yaitu, 42 orang/(84\%) memilih netral (3), 2 orang/(4\%) memilih setuju (4), dan 6 orang/(12\%) memilih tidak setuju (2). Kemasan busa jaring dari 50 responden yaitu, 2 orang/(8\%) memilih tidak setuju (2), 38 orang/(76\%) memilih netral (3) dan 8 orang/(16\%) memilih setuju (4) dan Kemasan anyaman bambu dari 50 responden yaitu, 2 orang/(4\%) memilih tidak setuju (2), 21 orang/(42\%) memilih netral (3) dan 27 orang/(54\%) memilih setuju (4). Alasan

\section{a. Kemasan Primer}

1. Kemasan busa jaring

Hasil analisis data kuesioner dari persepsi responden pada penelitian yang telah dilaksanakan menyatakan bahwa persepsi konsumen terhadap kepuasan kemasan busa jaring dari 50 responden yaitu, 2 orang/(8\%) memilih tidak setuju (2), 38 orang/(76\%) memilih netral (3) dan 8 orang/(16\%) memilih setuju (4)

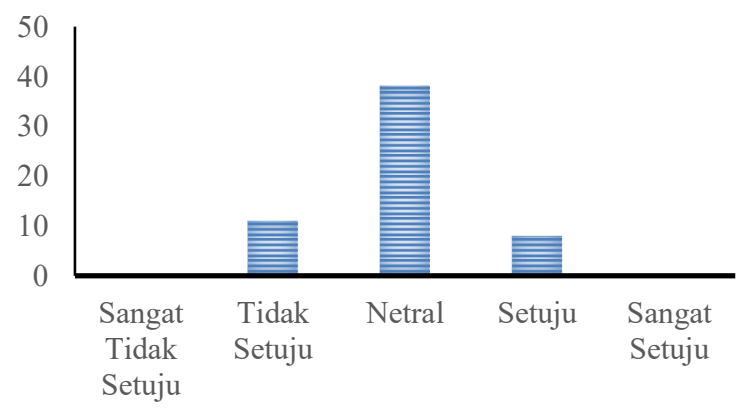

Gambar 16. Histogram persepsi kemasan busa jaring 


\section{b. Kemasan Sekunder}

\section{Kemasan daun kelapa}

Hasil analisis data kuesioner dari persepsi responden pada penelitian yang telah dilaksanakan menyatakan bahwa persepsi konsumen terhadap kepuasan kemasan anyaman daun kelapa dari 50 responden yaitu, 6 orang/(12\%) memilih netral (3), 40 orang/(80\%) memilih setuju (4) dan 4 orang/(8\%) memilih sangat setuju (5)

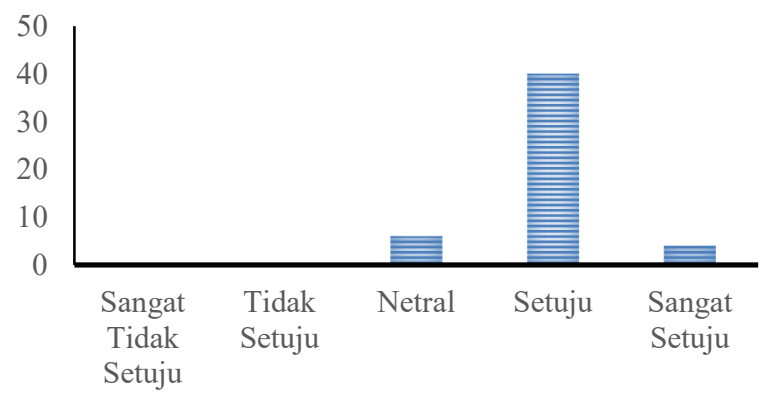

Gambar 17. Histogram persepsi kemasan daun kelapa

\section{Kemasan daun lontar kering}

Hasil analisis data kuesioner dari persepsi responden pada penelitian yang telah dilaksanakan menyatakan bahwa persepsi konsumen terhadap kepuasan kemasan anyaman daun lontar kering dari 50 responden yaitu, 42 orang/(84\%) memilih netral (3), 2 orang/(4\%) memilih setuju (4), dan 6 orang/(12\%) memilih tidak setuju (2).

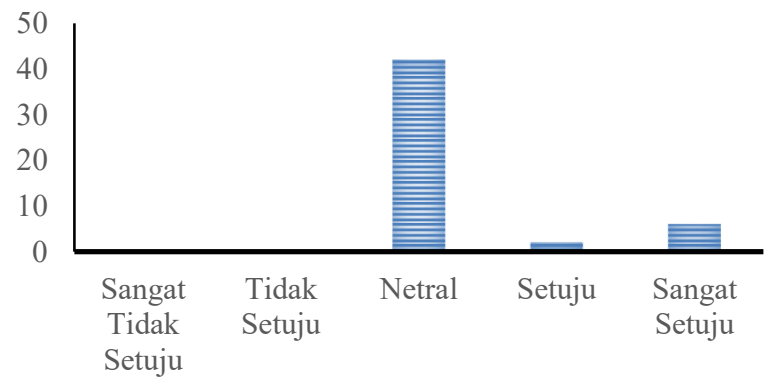

Gambar 18. Histogram persepsi kemasan daun lontar kering

\section{Kemasan anyaman bambu}

Hasil analisis data kuesioner dari persepsi responden pada penelitian yang telah dilaksanakan menyatakan bahwa persepsi konsumen terhadap kepuasan pada kemasan anyaman bambu dari 50 responden yaitu, 2 orang/(4\%) memilih tidak setuju (2), 21 orang/(42\%) memilih netral (3) dan 27 orang/(54\%) memilih setuju (4)

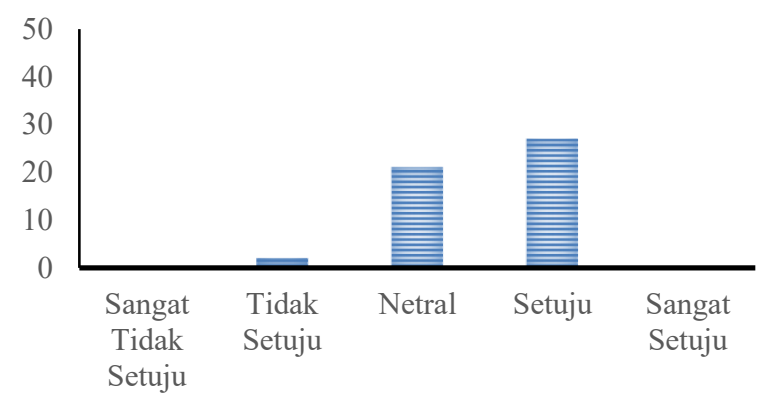

Gambar 19. Histogram persepsi kemasan anyaman bambu

\section{KESIMPULAN DAN SARAN}

\section{Kesimpulan}

Dari hasil penelitian survey yang telah dilakukan dapat disimpulkan, kemasan yang paling dominan menurut perpsepsi 50 responden yaitu:

1. Dari segi kualitas adalah kemasan daun kelapa dengan hasil 29 orang/(58\%) memilih setuju

2. Dari segi bahan dan disain adalah kemasan anyaman bambu dengan hasil, 29 orang/(58\%) memilih setuju.

3. Dari segi harga adalah kemasan anyaman bambu dengan hasil 31 orang/(62\%) memilih sangat setuju (5).

4. Dari segi kepuasan adalah kemasan daun kelapa dengan hasil, 40 orang/(80\%) memilih setuju (4).

\section{Saran}

Berdasarkan hasil penelitian yang telah dilakukan, saran yang dapat di berikan dalam penggunaan kemasan sebagai wadah dalam berbelanja yaitu sebaiknya menggunakan kemasan yang berbahan bambu, karena sesungguhnya dari segi kualitas bambu lebih kuat mengemban beban barang di bandingkan kemasan lain

\section{DAFTAR PUSTAKA}

Andrean, R. A., Sucipta, N., \& Kencana, P. K. D. (n.d.). Desain Kemasan dari Anyaman Bambu dan Pengaruh Terhadap Bobot, Tekstur, dan Warna Jaje Gambir Packaging Design ( Secondary) of woven bamboo and its Effect on Jaje Gambir characteristics .

Archer, L. B. (1965). Systematic Method For Designers. Council of Industrial Design.

Cindy, dwi fadhlan. (2016). Pengaruh Green Packaging Dan Marketing Mix Terhadap Keputusan Pembelian Pada Produk Teh Kotak (Studi Mahasiswa S1 Jurusan Manajemen Universitas Andalas). Universitas Andalas. http://scholar.unand.ac.id/16623/ 
Dede Nurrosyid. (2006). Penemu Plastik Jenis Bakelit. LIPI. http://www.fisikanet.lipi.go.id/utama.cgi?cetak artikel\&1164843618

FAJRIL, E. P. (2015). Pengaruh Pengetahuan, Sikap dan Gaya Hidup terhadap Keputusan Pembelian Ades dengan Kemasan Ramah Lingkungan (Doctoral dissertation, Universitas Andalas). Universitas Andalas.

Firdaus, F., Mulyaningsih, S., \& Anshory, H. (2008). Sintesis Film Kemasan Ramah Lingkungan Dari Komposit Pati, Khitosan dan Asam Polilaktat dengan Pemlastik Gliserol: Studi Morfologi dan Karakteristik Mekanik. Logika, 58(1), $1-14$. https://doi.org/10.20885/logika.vol5.iss1.art4

Ghozali. (2009). uji validitas digunakan untuk mengukur sah, atau valid tidaknya suatu kuesioner.

Harris, H. (2001). Kemungkinan Penggunaan edible Film Dari Pati Tapioka Untuk Pengemas Lempuk. Jurnal Ilmu-Ilmu Pertanian Indonesia, 3(2), 99-106.

Markkanen, P. K. (2004). Kesehatan dan Keselamatan Kerja di Indonesia. Internasional Labour Organisation Sub Regional South-East Asia And The Pacific Manila Philippines.

Noviadji. (2014). Desain kemasan tradisional dalam konteks kekinian. Artika.

Priambodo, a. K. (2017). Pengembangan kemasanramah lingkungan produk sambal dengan metode value analysis (Doctoral dissertation, Universitas Gadjah Mada). Universitas Gadjah Mada.

Pudjiastuti, W. (2010). Aplikasi Teknologi Kemasan yang Ramah Lingkungan dan Prospeknya. Jurnal Kimia Dan Kemasan 32.1 (2010): 19-26.

Rahman. (2011). Buah jambu biji Kristal dan penanganan pascapanen. Institut Pertanian Bogor.

Ratnawati, H., \& Putranti, D. (2016). Pengaruh Kemasan Ramah Lingkungan Dan Informasi Terhadap Minat Beli Ulang ( Studi Konsumen Amdk Kota Semarang ). Prosiding Seminar Nasional INDOCOMPAC, 87-98.

Santoso, I., \& Fitriani, R. (2016). Green packaging, green product, green advertising, persepsi, dan minat beli konsumen. Urnal Ilmu Keluarga \& Konsumen, 9(2), 147-158.

Sarnawi M Dasim. (2012). Implementasi Pendidikan Karakter Dalam Pembelajaran Sains Di Sekolah Dasar Universitas Pendidikan Indonesia. Thesis, 78-95.

Sucipta, I N., S. K. (2016). Pengemasan Pangan (Kajian Pengemasan yang Aman,Nyaman,Efektif dan Efisien). Udayana University Press.
Suherlan, Y., Muttaqin, H., Anam, C., \& Widiyanti, E. (2016). Model Balai Pengembangan Kemasan Ramah Lingkungan Untuk Meningkatkan Daya Saing Produk Lokal UMKM Pangan Olahan Menghadapi Pasar Global. In National Seminar Proceedings, The Increase of SME's Capability in Upgrading the SME. Solo: UNS.

Syukri, I. A. (2014). Fungsi dan Peranan Pengemasan Pangan. Universitas Andalas.

Titisari, P. (2013). Pengemasan Tradisional masa kini. Mitra Wacana Media.

Yuliati, Y., \& Hadiyati, R. (2018). Pelatihan pengemasan produk. Pengabdian Masyarakat, 1(2). 